\title{
CATALYTIC UPGRADING PYROLYSIS VAPORS OF JATROPHA WASTE USING METAL PROMOTED ZSM-5 CATALYSTS: AN ANALYTICAL PY-GC/MS
}

\author{
Supawan Vichaphund ${ }^{\mathrm{a}, \mathrm{b}}$, Duangdao Aht-ong ${ }^{\mathrm{a}, \mathrm{b}}$, Viboon Sricharoenchaikul $^{\mathrm{c}}$, \\ Duangduen Atong ${ }^{\mathrm{d}, *}$ \\ ${ }^{a}$ Department of Materials Science, Faculty of Science, Chulalongkorn University, \\ Bangkok,10330 Thailand \\ ${ }^{\mathrm{b}}$ Research Unit of Advanced Ceramics and Polymeric Materials, National Center of Petroleum, \\ Petrochemicals, and Advanced Materials, Chulalongkorn University, Bangkok, 10330, Thailand \\ ${ }^{\mathrm{c}}$ Department of Environmental Engineering, Faculty of Engineering, Chulalongkorn University, \\ Bangkok, 10330, Thailand \\ d, ${ }^{*}$ Ceramic Technology Research Unit, National Metal and Materials Technology Center, \\ Pathumthani, 12120, Thailand
}

*Corrensponding author:Tel.:+66-2-564-6500 Fax: +66-2-5645602

E-mail address: duangdua@mtec.or.th (D.Atong)

\begin{abstract}
HZSM-5 with high surface area of $625 \mathrm{~m}^{2} / \mathrm{g}$ was successfully synthesized by hydrothermal method at $160^{\circ} \mathrm{C}$ for $72 \mathrm{~h}$. The metal promoted on HZSM-5 catalyst was prepared by liquid ion exchange method. From XRD results, the addition of metals such as Co and Ni did not change the HZSM-5 structure. The metal/HZSM-5 showed lower crystallinity and surface area than the parent HZSM-5 because of the metal dispersion on the HZSM-5 surface. The metal contents of Co/ HZSM-5 and Ni/HZSM-5 detected by EDX were less than $1 \mathrm{wt} \%$. Catalytic fast pyrolysis of Jatropha waste using HZSM-5 and metals/HZSM-5 was investigated in terms of biomass to catalyst ratios (1:0, 1:1, 1:5 and 1:10) and types of metals (Co and Ni). From the results, it can be concluded that both biomass to catalyst ratios and the presence of metals had an effect on the increase in aromatic hydrocarbons yields as well as the decrease in the oxygenated and $\mathrm{N}$ containing compounds. Both Co/HZSM-5 and Ni/HZSM-5 promoted the production of aliphatic compounds. Additionally, the PAHs compounds such as napthalenes and indenes, which caused the formation of coke, could be inhibited by metal/HZSM-5, particularly, Ni/HZSM-5. Among catalysts, Ni/HZSM-5 showed the highest hydrocarbon yield of $97.55 \%$ with N-containing compounds remained only $1.78 \%$. The formation of hydrocarbon compounds increased the heating values of bio-oils while the elimination of the undesirable oxygenated compounds such as acids and ketones could alleviate problem regarding acidity and instability in bio oils.
\end{abstract}




\section{KEYWORDS}

ZSM-5, Catalyst, Pyrolysis, Jatropha waste, Py-GC/MS

\section{Introduction}

The attempt to utilize biomass as an alternative and clean renewable energy in the near future has received more attention due to the rising demand of the limited production of fossil fuel. Biomass can be converted to valuable fuels and chemicals via a number of processes including biological and thermochemical processes. Biomass is digested to smaller substances by bacterials or enzymes in biological conversion process. Therefore, this process is slower than thermochemical conversion. Among thermochemical conversion techniques, fast pyrolysis which is the thermal decomposition process at a high heating rate in the absence of oxygen is one of the most effective methods to convert solid biomass to high liquid yields, up to $75 \mathrm{wt} \%$, known as bio-oils [1- 3].

Generally, as-received bio-oils can be directly applied in boilers, industrial kilns, and gas turbines [1-2]. Unfortunately, the properties of bio-oil are obviously different from that of petroleum oil. In fact, the bio-oil contains the high oxygen contents almost $35-40 \mathrm{wt} \%$ due to their oxygen-rich compounds such as water, organic acid, ketone, aldehyde, phenolic compounds, and anhydrosugars. These components are responsible for poor fuel quality of bio-oils including low heating value, incompatibility with conventional fuel, high viscosity, chemical instability and acidity of bio-oils [2, 4]. In order to use bio-oil for transport fuel application, upgrading technologies by using cracking catalysts on pyrolysis vapors are of interest in order to reduce the oxygen contents via dehydration and decarboxylation reactions and also obtain higher hydrocarbon in bio-oils.

Several catalysts applied in this upgrading technology are metal oxide, microporous, and mesoporous materials via both lab scale-pyrolyzer and pyroprobe-GC/MS instruments as exhibited in Table 1. From previous researches, zeolites which were micro- and meso-porous materials have been demonstrated more effective to promote catalytic cracking reaction for deoxygenating oxygenated compounds as well as increasing hydrocarbon yields because of their superior properties such as high surface area, pore structure, molecular sieve characteristics, active site, and high thermal resistance.

Although, the high aromatic selectivity was attained by using microporous zeolites as catalysts, especially ZSM-5, some reported the problem such as fast deactivation causing by coke formation on the surface of zeolites $[4,5,9,10]$. In order to overcome this problem, the idea to incorporate transition metal into the framework to diminish polycyclic aromatic hydrocarbons (PAHs) led to coke formation as well as eliminate undesirable compounds was the major target. However, the zeolite modified by loading transition metals for upgrading technologies has been rarely reported as listed in Table 2.

Generally, the techniques for HZSM-5 modification by loading transition metals were 
conventional ion-exchange and impregnation. Impregnation technique seemed to be easier to prepare, however, the metal-support integration is weak and larger metal particles are usually achieved. In fact, most of metals are distributed on outer surface instead of acting as compensation ions into the framework. In contrast, ion-exchange method shows strong interaction between metal and support. P. Canizares et al. studied the effect of the metal loading methods for Ni- and $\mathrm{Pd} / \mathrm{H}-$ mordenite. The results showed that no difference between loading by ion exchange or impregnation when $\mathrm{Ni}$ acted as a metal site. However, the significant difference in the result was found with $\mathrm{Pd} / \mathrm{H}$-mordenite. Pd was present as small particles in the ion-exchange catalysts, but formed as clusters in the impregnated catalysts [15]. A.J. Maia et al. investigated the influence of nickel loading preparation (dry impregnation versus ionic exchange) on HZSM-5 support. Nickel tended to distribute as compensation cations in zeolite framework in case of ionic exchange preparation. Moreover, Ni-ZSM-5 catalyst prepared by ionic exchange method improved the formation of light olefin [16].

Thus, in this research, the addition of metals (Co and Ni) on HZSM-5 catalyst was prepared by conventional ion-exchange technique. The assumption of loading metal ion into the zeolite framework was to improve the activity of the catalyst in term of eliminating oxygenated compounds, increasing hydrocarbon and aromatic hydrocarbon yields as well as solving the coke formation during pyrolysis. The catalytic performances of Co/HZSM-5 and Ni/HZSM-5 were evaluated on the fast pyrolysis of Jatropha waste.

Jatropha curcus L. or physic nut, a small tree or large shrub, is one of the most attractive biomass sources for using as a biomass feedstock to produce biodiesel fuel because it is considered as producing non-edible plant oil at high yields. Furthermore, it is a drought-resistant tree which can be easily planted in all terrains and conditions $[17,18]$. After extraction process, the Jatropha wastes are the by-products which caused the disposal and environmental management problems. The utilization of this waste as biomass feedstock in pyrolysis seems to be the challenge and logical ways to solve these problems and moreover, create added value to this waste.

In this research Jatropha waste was catalytically pyrolyzed in a microscale reactor and pyrolytic products catalyzed by the catalysts were identified by using analytical pyrolysis-GC/MS (PyGC/MS) technique. The influence of the biomass to catalyst ratios (1:0,1:1, 1:5 and 1:10) and types of metals on composition of pyrolysis products were discussed.

\section{Material and Methods}

\subsection{Jatropha wastes}

Jatropha wastes left after extraction of oil during biodiesel production process from local plants in Thailand were used as a biomass feedstock. Prior to the test, it was dried at $60^{\circ} \mathrm{C}$ for $24 \mathrm{~h}$, crushed with a grinder, and then sieved to fine powders with the particle size equal or less than $125 \mu \mathrm{m}$ (100 mesh). Component analysis indicated that this material consisted of $59.20 \%$ cellulose, 
$18.00 \%$ hemicelluloses, and $22.80 \%$ lignin. The volatile matter and fixed carbon contents are $73.8 \%$ and $13.6 \%$, respectively, while ash contents of $5.8 \%$ are higher than approximately $1 \%$ usually found in wood. Carbon is the main element (49.2\%) with the small amount of $6.4 \%$ hydrogen, $4.5 \%$ nitrogen, and $1.1 \%$ sulfur. The oxygen contents of $39.6 \mathrm{wt} \%$ are considerably high which could lead to the formation of oxygenated pyrolysis liquid products.

\subsection{Catalyst preparation and characterization}

HZSM-5 catalyst was synthesized using sodium metasilicate pentahydrate ( $\geq 97 \%$, Fluka) as a silica source, sodium aluminate $\left(\mathrm{Al}_{2} \mathrm{O}_{3} 50-56 \%\right.$, Sigma-Aldrich) as an alumina source, tetrapropylammonium bromide (98\%, Aldrich) as a template, sulfuric acid (95-97\%, Merck) for $\mathrm{pH}$ adjustment, and ammonium chloride ( $\geq 99.5 \%$, Sigma-Aldrich) for ion-exchange process. The initial molar ratios of $\mathrm{SiO}_{2} / \mathrm{Al}_{2} \mathrm{O}_{3}, \mathrm{Na}_{2} \mathrm{O} / \mathrm{SiO}_{2}, \mathrm{H}_{2} \mathrm{O} / \mathrm{SiO}_{2}$, and $\mathrm{TPABr} / \mathrm{SiO}_{2}$ were $40,1.025,47.5$, and 0.1 , respectively. After mixing, the milky gel was obtained at room temperature and then transferred into a Teflon lined stainless steel autoclave with static condition in order to perform crystallization process. The synthesis temperature was maintained at $160^{\circ} \mathrm{C}$ for $72 \mathrm{~h}$. After that, the crystallized product was filtered, washed by deionized water, dried at $100^{\circ} \mathrm{C}$ overnight, and calcined at $540^{\circ} \mathrm{C}$ for $5 \mathrm{~h}$ in air atmosphere to remove the organic template. In order to obtain HZSM-5, the powder was converted to $\mathrm{H}$-form by ion-exchange with $1 \mathrm{M} \mathrm{NH}_{4} \mathrm{Cl}$ solution at $80^{\circ} \mathrm{C}$ for $8 \mathrm{~h}$. The sample was then washed with deionized water to remove chloride ions, dried at $100^{\circ} \mathrm{C}$ overnight, and then calcined at $540^{\circ} \mathrm{C}$ for $5 \mathrm{~h}$ in air atmosphere.

Metal/HZSM-5 catalysts were prepared by aqueous ion-exchange. The $1 \mathrm{~g}$ of HZSM-5 was ion-exchanged in $50 \mathrm{ml}$ of $0.01 \mathrm{M} \mathrm{Co}\left(\mathrm{NO}_{3}\right)_{2}$ and $\mathrm{Ni}\left(\mathrm{NO}_{3}\right)_{2}$ solution under stirring at $80^{\circ} \mathrm{C}$ for $8 \mathrm{~h}$. Then, the suspension was filtered and washed with deionized water to eliminate the remained salts. After drying at $100^{\circ} \mathrm{C}$ for $24 \mathrm{~h}$, the metal/HZSM-5 powders were heated at $5^{\circ} \mathrm{C} / \mathrm{min}$ to $540^{\circ} \mathrm{C}$ for calcination for $5 \mathrm{~h}$ in air atmosphere. For the reduction process, the catalysts were reduced at $540^{\circ} \mathrm{C}$ for $2 \mathrm{~h}$ in hydrogen atmosphere (flow rate of $10 \mathrm{ml} / \mathrm{min}$ ), assigned as Co/HZSM-5 and Ni/HZSM-5.

Phase analysis of synthesized powder was performed by X-ray powder diffraction (XRD; PAN alytical, $X^{\prime}$ Pert Pro) with $40 \mathrm{kV}, 45 \mathrm{~mA}, \mathrm{CuK}_{\alpha}$ radiation. The sample was scanned at $2 \theta$ from 5 to $60^{\circ}$ with a step size of 0.02 . The degree of crystallinity was calculated by using the major peaks between $2 \theta$ of $22-25^{\circ}[19]$. Microstructure was characterized by scanning electron microscope (SEM; JEOL, JSM-5410). For analysis of metal dispersion of catalysts, Energy dispersive X-ray spectroscope (EDS; model Oxford Inca 300) with X-ray dot mapping was used. The specific surface area was measured by nitrogen adsorption using Autosorb-1 (Quantachrome instruments). The samples were degassed for $8 \mathrm{~h}$ at $300^{\circ} \mathrm{C}$ prior to the analysis.

\subsection{Catalytic test}

Pyrolysis was performed using a Pyroprobe pyrolyser (multi funtional pyrolyzer, PY-2020iD, 
Frontier Lab) with an auto-shot sampler AS-1020E interfaced to a gas chromatograph coupled to a mass selective detector (GCMS-QP2010, Shimadzu). In order to investigate the effect of catalyst content, catalysts were placed above $0.4 \mathrm{mg}$ of biomass (Jatropha wastes) layer in the amount of 0 , $0.4,2.0$, and $4.0 \mathrm{mg}$ to obtain the biomass to catalyst ratios of $1: 1,1: 5$, and $1: 10$, respectively. Then, the sample was pyrolyzed with the Pyroprobe set at $500^{\circ} \mathrm{C}$ and held for $30 \mathrm{~s}$. The pyrolysis vapors were then flushed to and identified by GC/MS. The column used was a $30 \mathrm{~m} \times 0.25 \mathrm{~mm}$ Ultra alloy 5 (i.d., $0.25 \mu \mathrm{m}$ film thickness). Helium (99.999\%) was used as a carrier gas with a column flow of $1.3 \mathrm{ml} / \mathrm{min}$, and the split injector ratio was 1:50. During the analysis of the pyrolytic products, the oven temperature was started from $50^{\circ} \mathrm{C}(3 \mathrm{~min})$ to $200^{\circ} \mathrm{C}$ (heating rate of $5^{\circ} \mathrm{C} / \mathrm{min}$ ) then to $350^{\circ} \mathrm{C}$ (heating rate of $10^{\circ} \mathrm{C} / \mathrm{min}$, held for $10 \mathrm{~min}$ ). The injector and detector temperature was kept at $280^{\circ} \mathrm{C}$, and the mass spectrometer was operated in EI mode at $70 \mathrm{eV}$. The mass spectra were obtained from m/z 20 to 800 with the scan speed of $625 \mathrm{amu} / \mathrm{s}$. Identification of chromatographic peaks was achieved according to the NIST and Wiley mass spectrum library. The major compounds in the vapors of the pyrolysis of Jatropha residue were arranged into 10 categories based on their major chemical functional groups which are aromatic, hydrocarbons, carboxylic acids, alcohol, ether, ester, ketone, phenol, sugar, and N-compound.

Due to complexity of products obtained from the pyrolysis process, it is not generally practical to make direct quantification of these compounds via traditional calibrated peak area procedure. Many studies rely on comparison among corresponding peak area of these compounds to express the selectivity of particular products. In the work reported here, product quantification is based on percentages of relative peak area of each compound to the total peak areas obtained from the chromatogram. These relative peak areas are then added up according to their associated categories and selectivity of particular group of compounds is then realized. For establishing of baseline measurement, Jatropha waste was also tested for comparison.

\section{Results and discussion}

\subsection{Catalyst characterization}

Phase analysis of synthesized HZSM-5 and metal/HZSM-5 was determined by XRD technique as demonstrated in Fig. 1. It was confirmed that the high crystallinity of synthesized HZSM-5 was obtained (orthorhombic form, JCPDS: 44-0003) (Fig. 1 (a)). The main peaks of synthesized HZSM5 zeolite were presented at the $2 \theta$ of $7.9^{\circ}, 8.8^{\circ}, 23.1^{\circ}, 23.9^{\circ}$, and $24.4^{\circ}$ which are in the range of typical specific peaks of ZSM-5 $\left(2 \theta=7-9^{\circ}\right.$ and $\left.23-25^{\circ}\right)[19]$.

The X-ray diffraction (XRD) patterns of both metal exchanged HZSM-5zeolites (Fig. 1 (b) and (c) were found to be similar to HZSM-5 indicating that the addition of Co and Ni by ion-exchange technique did not change the HZSM-5 structure. However, the metal/HZSM-5 catalysts were shown to have lower crystallinity than the parent HZSM-5 as displayed in Table 3. The reason might be because of the metal dispersion on the HZSM-5 surface causing the decrease in the degree of 
crystallinity (\%). The metal contents on HZSM-5 catalyst detected by Energy dispersive X-ray spectroscope was in a small amount of less than $1 \mathrm{wt} \%$.

The morphologies of synthesized HZSM-5, Co/HZSM-5, and Ni/HZSM-5 are exhibited in Fig. 2. HZSM-5 powders appeared in agglomeration due to the interconnection of particles with size less than $5 \mu \mathrm{m}$. The single particles of these HZSM-5 catalysts tended to grow into cubic shape. SEM micrographs of metal/HZSM-5 (Fig. 2 (b),(c)) revealed the same morphologies as their HZSM-5 supports. The Co and Ni particles could not be observed at this magnification because they were presented in small amount. From X- ray mapping displayed in Fig. 3, white spots represented the distribution of $\mathrm{Si}, \mathrm{Al}, \mathrm{Co}$, and $\mathrm{Ni}$ elements. The distributions of $\mathrm{Si}$ and $\mathrm{Al}$ were quite uniformly dispersed on the surface of the HZSM-5, while the dispersion of Co and Ni were barely observed due to their small amounts aforementioned.

The $\mathrm{Si} / \mathrm{Al}$ ratios were determined by EDX as shown in Table 3. It was found that the $\mathrm{Si} / \mathrm{Al}$ ratios of parent HZSM-5 and metal/ HZSM-5 was approximately 17-21. The HZSM-5 had high

surface area of $625 \mathrm{~m}^{2} / \mathrm{g}$, while surface areas of Co/HZSM-5 and Ni/HZSM-5 were also close to the former one.

\subsection{Catalytic performance}

These experiments studied the effect on the pyrolytic products of the ratio of biomass to metal/HZSM-5. Catalytic fast pyrolysis primarily involved pyrolysis of Jatropha waste into volatiles organic, gases, and solid. The volatile organics undertake reactions such as dehydration, decarboxylation, or decarbonylation to generate aromatic, carbon monoxide, carbon dioxide, and water inside HZSM-5 structure [20]. The overall product yields including gas, liquid and solid from fast pyrolysis of Jatropha waste with and without catalysts were shown in Fig. 4. Gas and liquid yields were determined by relative percentages of peak area directly obtained from the chromatogram of GC after normalization of the corresponding total product yields, whereas solid residues were calculated by the weight difference of samples before and after pyrolysis.

It can be seen that the large amount of gas were observed in the range of $15-22 \%$. From the analysis, most of the gas product was carbon dioxide with an insignificant amount of carbon monoxide. In addition, the presence of HZSM-5 and metal/HZSM-5 catalysts increased the gas formation. Larger amount of catalyst led to superior secondary cracking and decomposition reactions of liquid product resulting in higher gas yields at those conditions. Solid residues were in the range of 30-36\%, which were comparable to other works [14, 21, 22]. With increasing catalyst contents, solid residues from Jatropha waste pyrolyzed using HZSM-5 showed higher yields than that from non-catalytic Jatropha waste due to more activity of catalyst resulting in higher coke formation on HZSM-5 surface. Regardless catalyst content, lesser amount of solid yields with the addition of Co and Ni on HZSM-5 suggested that these metals contributed to reduce the coke formation on the zeolite surface while increasing the liquid yields. 


\subsubsection{Biomass to catalysts ratios}

The yield of pyrolysis products was affected by the difference in active metals to some extent. On the other hand, the compositions of liquid products were depended on type of metal loading as well as catalyst content. The pyrolytic vapors (liquid yields) detected from GC/MS were displayed in Fig. 5 and Table 4. The non-catalytic pyrolytic liquid products (Fig. 5 (1)) consisted of 10 organic compounds. The main compound was acid (50.7\%), which was mainly linoleic acid (C18:2) (37\%). It is known that this compound is one of the main unsaturated fatty acid compositions found in Jatropha oils [17]. Naturally, the nitrogen element in Jatropha is higher than other woody biomass. Consequently, N-containing compounds in pyrolytic product were found in high content (20.3\%). Other oxygenated compounds consisted of ketones, (7.52\%), alcohols (3\%), esters $(1.99 \%)$, ethers $(3.72 \%)$, and phenols $(2.82 \%)$. The heavy compounds such as sugar products were found in small content, $3.66 \%$. In addition, the pyrolytic products contained small amounts of aromatic hydrocarbon (3.03\%) and aliphatic HC (1\%).

With catalyst, the intermediate oxygenated compounds diffused into ZSM-5 pores and reacted with the proton at active site (intersection channel) via various reaction pathways including dehydration, decarboxylation, decarbonylation, and oligimerization [20]. At low content of catalysts (Jatropha:catalyst ratio of 1:1) (Fig. 5(2)-(4)), the results showed that both HZSM-5 and metal/HZSM-5 catalysts promoted the formation of both aromatic and aliphatic hydrocarbons through effective deoxygenation of acid fractions. The presence of HZSM-5 increased the yields of aromatic hydrocarbon from 3 to $22.62 \%$ and aliphatic hydrocarbon from 1 to $7.81 \%$, respectively. Furthermore, the addition of metals such as $\mathrm{Co}$ and $\mathrm{Ni}$ further contributed to enhancement of hydrocarbon yields compared to HZSM-5 because metal/HZSM-5 acted as a bifunctional catalyst, which included both acid and metal sites to increase the aromatization and alkylation reactions. It was noticed that Ni/HZSM-5 showed the highest hydrocarbon yields of $34.76 \%$. However, the pyrolytic products with low catalyst content $(1: 1)$ yet contained several oxygenated compounds such as acid, alcohol, ester, ketone, phenol, and large amount of N-containing compounds.

When the amount of catalyst increased (Jatropha:catalyst=1:5), the yields of other oxygenatedand N-compounds decreased significantly. At the same time, the yields of aromatic hydrocarbon increased rapidly up to $87.85 \%, 85.19 \%$ and $85.97 \%$ for HZSM-5, Co/HZSM-5, and Ni/HZSM-5, respectively. These results showed that the metal loaded on HZSM-5 influenced insignificantly on the improvement of aromatic yields. The reason might be due to a small amount of metal of less than $1 \mathrm{wt} \%$ as stated previously. However, the presence of metals promoted on HZSM-5 could slightly increase aliphatic hydrocarbon yields. Thus, the summation of hydrocarbon selectivity obtained from Co/HZSM-5 and Ni/HZSM-5 was considerably high as 88 and $89.29 \%$ which can be compared to the yield obtained from HZSM-5 (88.62\%). Hydrocarbon compounds such as aliphatic and aromatic were desirable products from pyrolytic vapors because of their high heating value 
properties $[4,6]$.

Fig. 5 (8)-(10) clearly showed the aromatic selectivity for the catalytic fast pyrolysis of Jatropha wastes as a function of biomass:catalyst ratios. At the highest catalyst content (the Jatropha: HZSM$5=1: 10$ ), the hydrocarbon yields improved significantly which are desirable pyrolytic products

expected in bio-oils. HZSM-5 with high surface area of $625 \mathrm{~m}^{2} / \mathrm{g}$ produced the highest aromatic hydrocarbon yields of $96.3 \%$ while the small amounts of some oxygenated compounds were detected such as ester, alcohol, and acid. These oxygenated compounds resulted in poor properties such as instability and more acidity in bio-oils $[5,7]$. Another undesirable product, N-containing compounds, remained only $1.61 \%$. The result of higher aromatic hydrocarbon yields by using high content of HZSM-5 corresponded well to other works. S. Thangalagalazhy-Gopakumar et al. reported that the increase of biomass to ZSM-5 ratios from 1:4 to 1:9 had an effect on the increase of aromatic compounds yields from the pyrolysis vapors of pine wood chip catalyzed by ZSM-5 with high surface area of $425 \mathrm{~m}^{2} / \mathrm{g}$ [23]. T.R. Calson et al. studied the effect of catalyst to glucose ratios for catalytic fast pyrolysis using ZSM-5 as a catalyst with a variety of catalyst to biomass ratios of $19,9,4,2.3,1.5$, respectively. The high aromatic selectivity was obtained with the highest catalyst to feed ratio of 19 [24]. For metal/HZSM-5, both Co/HZSM-5 and Ni/HZSM-5 catalysts showed slightly less active to produce aromatic hydrocarbon yields, while showed better aliphatic selectivity than HZSM-5. However, there was no significant alteration in aromatic selectivity by loading of different metals, Co and Ni, on HZSM-5. In addition, metal/HZSM-5 could eliminate most oxygenated compounds found in non-catalytic pyrolytic products such as acid, alcohol, ketone, phenol, and significantly decreased N-containing compounds.

From these results, it can be concluded that the biomass to catalyst ratio has an effect on the increase of aromatic hydrocarbons yields as well as the decrease in the oxygenated and Ncontaining compounds. In addition, the metal promoted on HZSM-5 led to the formation of aliphatic compounds. Among all catalysts, Ni/HZSM-5 produced the highest hydrocarbon yield of $97.55 \%$.

\subsubsection{The addition of metals}

In order to investigate how metals such as $\mathrm{Co}$ and $\mathrm{Ni}$ affect the aromatic selectivity, the major aromatic compounds catalyzed by high catalyst contents (Jatropha:catalyst ratios = 1:5 and 1:10) were monitored. The selectivity of main aromatic compounds such as benzene, toluene, ethylbenzene, xylene including polycyclic aromatic compounds which were indene and napthalene compounds were studied as shown in Fig. 6. It can be seen that aromatic selectivity increased with the increase in catalyst content.

At moderate catalyst content (Jatropha:Catalyst=1:5), the aromatic selectivity with HZSM-5 was toluene $=$ xylene $>$ napthalenes $>$ benzene $>$ ethylbenzene $>$ indenes. Co/HZSM-5 promoted slightly the higher selectivity for ethylbenzene and indenes, while the benzene and xylene yields decreased 
significantly. The presence of Ni/HZSM-5 enhanced greatly the toluene selectivity, while the benzene yields decreased gradually. This probably resulted from further reaction of benzene with other oxygenated compounds to form alkylated benzene such as toluene and xylene [13]. Furthermore, both Co/HZSM-5 and Ni/HZSM-5 considerably inhibited the increase in naphthalene selectivity. Napthalenes, which were polycyclic aromatic hydrocarbons (PAHs), caused the formation of coke, which leads to the catalyst deactivation.

At high catalyst content (Jatropha:Catalyst $=1: 10$ ), all catalysts produced high aromatic compounds yields as discussed earlier. The aromatic selectivity with HZSM-5 was toluene $>$ xylene $>$ napthalenes $>$ benzene $>$ indenes $>$ ethylbenzene. It was confirmed that HZSM-5 favored to produce toluene $\left(\mathrm{C}_{7}\right)$, xylene $\left(\mathrm{C}_{8}\right)$, benzene $\left(\mathrm{C}_{6}\right)$, and naphthalene compounds $\left(\mathrm{C}_{10}-\mathrm{C}_{12}\right)$ including small amounts of ethylbenzene $\left(\mathrm{C}_{8}\right)$ and indene compounds $\left(\mathrm{C}_{9}-\mathrm{C}_{11}\right)$. The main aromatic compounds produced from HZSM-5 catalyst were in the range of gasoline $\left(\mathrm{C}_{5}-\mathrm{C}_{12}\right)$ [25]. With Co/HZSM-5, the highest aromatic selectivity was $28 \%$ toluene and $23 \%$ xylene, while naphthalene compounds noticeably decreased. The presence of Ni/HZSM-5 showed the similar highest aromatic selectivity of toluene and xylene. In addition, the decrease in naphthalene and indene compounds was found when Ni/HZSM-5 was used as a catalyst. The deterioration of PAHs seemed to be good performing of catalysts because it expected to reduce the deactivation on the surface of HZSM-5. This assumption was in good agreement with the work of R. French et al. Biomass feedstocks (cellulose, lignin and wood) were pyrolyzed using catalyst to biomass ratios of 5-10. The highest yield of hydrocarbons was attained using $\mathrm{Ni}, \mathrm{Co}, \mathrm{Fe}$ and Ga-substituted ZSM-5. Interestingly, the lower coke formation was obtained when applied Co/ZSM-5 and Ni/ZSM-5 as catalysts [14].

\section{Conclusions}

HZSM-5 with high surface area of $625 \mathrm{~m}^{2} / \mathrm{g}$ was synthesized by hydrothermal method. The metal was loaded on the HZSM-5 by conventional ion exchange method. The addition of Co and Ni metals did not change the HZSM-5 structure. Catalytic fast pyrolysis of Jatropha waste using HZSM-5 and metals/HZSM-5 was investigated in terms of biomass to catalyst ratios (1:0, 1:1, 1:5 and 1:10) and types of metals (Co and Ni). Both HZSM-5 and metals/HZSM-5 promoted the formation of aromatic and aliphatic hydrocarbons. In addition, high catalyst content had an effect on the increase of aromatic hydrocarbons yields as well as the decrease in the oxygenated and Ncontaining compounds. The metal - containing HZSM-5 showed slightly lesser aromatic selectivity than HZSM-5 but contributed to increase overall hydrocarbons yields and decreased the oxygenated compounds. Among catalysts, Ni/HZSM-5 produced the highest hydrocarbon yield of $97.55 \%$, reduced PAHs, and contained N-containing compounds of only $1.78 \%$. The formation of hydrocarbon compounds increased the heating values of bio-oils while the elimination of the undesirable oxygenated compounds could alleviate acidity and instability in bio oils. 
Pyroprobe-GC/MS is an effective experiment in order to screen the primary catalytic performance in the small scale pyrolyzer. Ni/HZSM-5 showed superior performance among others and will be further applied in a continuous feed fixed bed pyrolyzer in future work.

\section{Acknowledgments}

This research is granted by the National Metal and Materials Technology Center, Thailand (Project No.MT-B-53-END-07-082-C). The Py-GC/MS was supported by JST/JICA, Science and Technology Research Partnership for Sustainable Development (SATREPS), Japan. S.Vichaphund would like to acknowledge Research Unit of Advanced Ceramics and Polymeric Materials, National Center of Petroleum, Petrochemicals, and Advanced Materials, Chulalongkorn University, Pathumwan, Bangkok, Thailand for financial support. Integrated Innovation Academic Center : IIAC Chulalongkorn University Centenary Academic Development Project (CU56-EN12) and the Higher Education Research Promotion and National Research University Project of Thailand, Office of the Higher Education Commission (EN1189A-56) are also thanked for their partially support of this work.

\section{References}

[1] Bridgwater, A.V., Review of fast pyrolysis of biomass and product upgrading, Biomass Bioenerg. 2012; 38: 68-94.

[2] Czernik, S., Bridgwater, A.V., Overview of application of biomass fast pyrolysis oil. Energ. Fuel. 2004; 18: 590-598.

[3] Van de Velden, M., Baeyens, J., Brems, A., Janssens, B., Dewil, R., Fundamentals, kinetics and endothermicity of the biomass pyrolysis reaction, Renew. Energ. 2010; 35: 232-242.

[4] Lu,Q., Zhang, Z.-F., Dong, Zhu, X.-F., Catalytic upgrading of biomass fast pyrolysis vapors with nano metal oxides:an analytical Py-GC/MS study, Energy. 2010; 3: 1805-1820.

[5] Lu, Q., Zhang, Y., Tang, Z., Li, W.Z., Zhu, X.F., Catalytic upgrading of biomass fast pyrolysis vapors with titania and zirconia/titania based catalysts, Fuel. 2010; 89: 2096-2013.

[6] Stefanidis, S.D., Kalogiannis, K.G., Ilipoulou, E.F., Lappas, A.A., Pilavachi., P.A., In-situ upgrading of biomass pyrolysis vapors:catalyst screening on a fixed bed reactor, Bioresource. Technol. 2011; 102: 8261-8267.

[7] Pattiya A., Titiloye, J.O., Bridgwater., A.V., Fast pyrolysis of cassava rhizome in the presence of catalysts. J. Anal. Appl. Pyrolysis. 2007; 81: 72-79.

[8] Mihalcik, D.J., Mullen, C.A., Boateng, A.A., Screening acidic zeolites for catalytic fast pyrolysis of biomass and its components, J. Anal. Appl. Pyrolysis. 2011; 92: 224-232.

[9] Aho, A., Kumar, N., Eranen, K., Salmi, T., Hupa, M., Murzin, D.Y., Catalytic pyrolysis of woody biomass in a fluidized bed reactor: Influence of the zeolite structure, Fuel. 2008; 87: 2493- 
2501.

[10] Qiang, L., Wen-zhi, L., Dong, Z., and Xi-feng, Z., Analytical pyrolysis-gas chromatography/mass spectrometry (Py-GC/MS) of saw dust with AL/SBA-15 catalysts. J. Anal. Appl. Pyrolysis. 2009; 84: 131-138.

[11] Sulman, E.M., Alferov, V.V, Kosivtsov, Y.Y., Sidorov, A.I., Misnikov, O.S., Afanasiev, A.E., Kumar, N., Kubicka, D., Agullo, J., Salmi, T., Murzin., D.Y., The development of the method of low-temperature peat pyrolysis on the basis of aluminosilicate catalytic system, Chem. Eng. J. 2007; 134: 162-167.

[12] Murata, K., Liu, Y., Inaba, M., Takahara, I., Catalytic fast pyrolysis of jatropha waste. J. Anal. Appl. Pyrolysis. 2012; 94: 75-82.

[13] Thangalazhy-Gopakumar, S., Adhikari, S., Gupta, R.B., Catalytic pyrolysis of biomass over $\mathrm{H}^{+}$ZSM-5 under hydrogen pressure, Energ. Fuel. 2012; 26: 5300-5306.

[14] French, R., Czernik, S., Catalytic pyrolysis of biomass for biofuels production, Fuel. Process. Technol. 2010; 91: 25-32.

[15] Canizares, P., de Lucas, A., Dorado, F., Duran, A., Asencio, I., Characterization of Ni and Pd supported on H-mordenite catalysts: Influence of the metal loading method, Appl. Catal. A-Gen. 1998; 169: 137-150.

[16] Maia, A.J., Louis, B., Lam, Y.L., Pereira, M.M., Ni-ZSM-5 catalysts: Detailed characterization of metal sites for proper catalyst design, J. Catal. 2010; 269:103-109.

[17] Achten, W.M.J., Verhot, L., Franken, Y.J., Mathijs, E., Singh, V.P., Aerts, R., Muys, B., Jatropha bio-diesel production and use, Biomass Bioenerg. 2008; 32, 1063-1084.

[18] Koh, M.Y., Ghazi, T.I.M., A review of biodiesel production from Jatropha curcus L. oil, Renew. Sust. Energ. Rev., 2011; 15: 2240-2251.

[19] Szostak., R., Molecular sieves-principles of synthesis and identification. second ed., London: Blackie Academic\& Professional: Thomson Science; 1998.

[20] Carlson, T.R., Chenge, Y.-T., Jae, J., Huber, G.W., Production of green aromatics and olefins by catalytic fast pyrolysis of wood sawduct, Energy Environ. Sci., 2011; 4: 145-161.

[21] Mochizuki, T., Atong, D., Chen S.-Y., Toba, M., Yoshimura, Y., Effect of $\mathrm{SiO}_{2}$ pore size on catalytic fast pyrolysis of Jatropha residues by using pyrolyzer-GC/MS, Catal. Commun., 2013; 36: $1-4$.

[22] Mochizuki, T., Chen S.-Y., Toba, M., Yoshimura, Y., Pyrolyzer-GC/MS system-based analysis of the effects of zeolite catalysts on the fast pyrolysis of Jatropha husk, Appl. Catal. A-Gen., 2013; 456: 174-181.

[23] Thangalazhy-Gopakumar, S., Adhikari, S., Gupta, R.B., Tu, M., Taylor, S., Production of hydrocarbon fuels from biomass using catalytic pyrolysis under helium and hydrogen environments, Bioresource Technol., 2011; 102: 6742-6749. 
[24] Carlson, T.R., Tompsett, G.A., Conner, W.C., Huber, G.W., Aromatic production from catalytic fast pyrolysis of biomass-derived feedstocks, Top. Catal., 2009; 52: 241-252.

[25] Escola, J.M., Aguado, J., Serrano, D.P., Briones, L., Diaz de tuesta, J.L., Calvo, R., Fernandez, E., Conversion of polyethylene into transportation fuels by the combination of thermal cracking and catalytic hydroreforming over Ni-supported hierarchical beta zeolite, Energ. Fuel. 2012; 26: 31873195. 
Table 1 Metal oxide and porous catalysts applied in catalytic upgrading technology

\begin{tabular}{|c|c|c|c|c|c|c|}
\hline Authors & Materials & Catalysts & Biomass & Reactors & Results & References \\
\hline $\begin{array}{l}\text { Q. Lu et al. } \\
\text { (2010) }\end{array}$ & Metal oxide & $\begin{array}{l}\mathrm{MgO}, \mathrm{CaO}, \mathrm{TiO}_{2}, \\
\mathrm{Fe}_{2} \mathrm{O}_{3}, \mathrm{NiO} \text {, and } \mathrm{ZnO}\end{array}$ & Poplar wood & Py-GC/MS & $\begin{array}{l}\text {-All catalysts showed the effective to } \\
\text { decrease oxygenated products } \\
\text {-Low HC yield, } 4 \%\end{array}$ & [4] \\
\hline $\begin{array}{l}\text { Q. Lu et al. } \\
\text { (2010) }\end{array}$ & Metal oxide & $\begin{array}{l}\mathrm{TiO}_{2} \text { (Rutile), } \\
\mathrm{TiO}_{2} \text { (Anatase), } \\
\mathrm{ZrO}_{2} \& \mathrm{TiO}_{2}\end{array}$ & Poplar wood & Py-GC/MS & $\begin{array}{l}-\mathrm{ZrO}_{2} \& \mathrm{TiO}_{2} \text { based catalysts were the most } \\
\text { effective to reduce phenols, acids, and } \\
\text { sugars } \\
\text {-Low HC yield, } 13 \%\end{array}$ & [5] \\
\hline $\begin{array}{l}\text { S.D. Stefanidis } \\
\text { et al. } \\
(2011)\end{array}$ & $\begin{array}{l}\text { Metal oxide, } \\
\text { microporous }\end{array}$ & $\begin{array}{l}\text { FCC, ZSM-5, MgO, } \\
\mathrm{NiO} \text {, Alumina, } \\
\mathrm{ZrO}_{2} / \mathrm{TiO}_{2} \text {, silica } \\
\text { alumina }\end{array}$ & $\begin{array}{l}\text { A commercial } \\
\text { wood biomass }\end{array}$ & Fixed bed & $\begin{array}{l}\text {-ZSM-5 exhibited high HC selectivity, } \\
\text { reducing undesirable compounds, } \\
\text { producing the acceptable liquid yields }\end{array}$ & {$[6]$} \\
\hline $\begin{array}{l}\text { A. Pattiya et al. } \\
\text { (2008) }\end{array}$ & $\begin{array}{l}\text { Metal oxide, } \\
\text { mesoporous, } \\
\text { microporous }\end{array}$ & $\begin{array}{l}\text { ZSM-5, Al-MCM-41, } \\
\text { MSU-F, commercial } \\
\text { catalyst }\left(\mathrm{Al}_{2} \mathrm{O}_{3}\right. \\
\text { stabilised ceria) }\end{array}$ & $\begin{array}{l}\text { Cassava } \\
\text { rhizome }\end{array}$ & Py-GC/MS & $\begin{array}{l}\text {-ZSM-5 was the most active to all the } \\
\text { change in pyrolytic products }\end{array}$ & [7] \\
\hline $\begin{array}{l}\text { Mihalcik et al. } \\
\text { (2011) }\end{array}$ & Microporous & $\begin{array}{l}\text { ZSM-5, Y, Beta, } \\
\text { Mordenite, Ferrierite }\end{array}$ & $\begin{array}{l}\text { Lignocellulosic } \\
\text { biomass }\end{array}$ & Py-GC/MS & $\begin{array}{l}\text {-ZSM-5 was the most effective at } \\
\text { producing aromatic HC products. }\end{array}$ & [8] \\
\hline $\begin{array}{l}\text { A. Aho et al. } \\
(2008)\end{array}$ & Microporous & $\begin{array}{l}\text { Beta, Y, ZSM-5, } \\
\text { Mordenite }\end{array}$ & $\begin{array}{l}\text { Woody } \\
\text { biomass }\end{array}$ & $\begin{array}{l}\text { Fluidized } \\
\text { bed }\end{array}$ & $\begin{array}{l}\text { - Pyrolytic product yields was slightly } \\
\text { affected by the different zeolite structures } \\
\text { - The formation of acid and alcohol over } \\
\text { ZSM-5 was lower than others } \\
\text { - The coke deposition on ZSM-5 seemed to } \\
\text { be less than others }\end{array}$ & [9] \\
\hline
\end{tabular}


Table 2 Zeolite modified by loading transition metals for upgrading technologies

\begin{tabular}{|c|c|c|c|c|c|c|}
\hline Authors & Materials & Catalysts & Biomass & Reactors & Results & References \\
\hline $\begin{array}{l}\text { E.M. Sulman et } \\
\text { al.(2007) }\end{array}$ & Microporous & $\begin{array}{l}\text { Beta, Y, Mordenite, } \\
\text { ZSM-5, Fe/zeolites }\end{array}$ & Peat & Fixed bed & $\begin{array}{l}\text {-The presence of iron displayed higher } \\
\text { activity than H-formed zeolites, for } \\
\text { example, the formation of light HC }\end{array}$ & [11] \\
\hline $\begin{array}{l}\text { K. Murata et al. } \\
\text { (2012) }\end{array}$ & $\begin{array}{l}\text { Mesoporous, } \\
\text { microporous }\end{array}$ & $\begin{array}{l}\text { H-ZSM5, Beta-zeolite, } \\
\text { HY zeolite, Ferrierite, } \\
\text { Mordenite, USY, } \\
\text { SAPO-34, synthesized } \\
\text { ZSM-11 including } \\
\text { La/H-ZSM5 }\end{array}$ & Jatropha waste & Py-GC/MS & $\begin{array}{l}\text {-The aromatic selectivity depended on } \\
\text { both the pore structure and the nature of } \\
\text { acidity. } \\
\text {-H-ZSM5 showed better aromatic } \\
\text { selectivity than La/H-ZSM5 }\end{array}$ & [12] \\
\hline $\begin{array}{l}\text { S.Thangalazhy- } \\
\text { Gopakumar et } \\
\text { al. (2012) }\end{array}$ & Microporous & $\begin{array}{l}\text { Metal/HZSM-5. } \\
(\mathrm{Ni}, \mathrm{Co}, \mathrm{Mo}, \mathrm{Pt})\end{array}$ & Pine wood & Py-GC/MS & $\begin{array}{l}\text {-All metal/HZSM-5 catalysts increased } \\
\text { the aromatic yields compared to HZSM-5 } \\
\text { as a support }\end{array}$ & [13] \\
\hline $\begin{array}{l}\text { R. French et al. } \\
\text { (2010) }\end{array}$ & $\begin{array}{l}\text { Mesoporous, } \\
\text { microporous }\end{array}$ & $\begin{array}{l}10 \text { commercial zeolites } \\
\text { (ZSM-5, Y, SAPO), } \\
22 \text { laboratory-prepared } \\
\text { ZSM5 modified by } \\
\text { metals (Co,Fe, Ni, } \\
\text { Ce,Ga, Cu,Na) }\end{array}$ & $\begin{array}{l}\text { Cellulose, } \\
\text { lignin and } \\
\text { wood }\end{array}$ & $\begin{array}{l}\text { Micro- } \\
\text { reactor/MBMS }\end{array}$ & $\begin{array}{l}\text {-The highest yield of HC was attained } \\
\text { using Ni, Co, Fe and Ga-substituted ZSM- } \\
5 \text {. } \\
\text {-The lower yield of coke formation was } \\
\text { obtained by using Co/ZSM-5 and } \\
\text { Ni/ZSM-5 }\end{array}$ & [14] \\
\hline
\end{tabular}


Table 3 Properties of zeolite catalysts

\begin{tabular}{cccccc}
\hline Catalysts & Crystallinity & $\begin{array}{c}\text { Surface } \\
\text { area }\end{array}$ & Si/Al & \multicolumn{2}{c}{ Element (wt\%) } \\
\cline { 5 - 6 } & $(\%)$ & $\left(\mathrm{m}^{2} \mathrm{~g}^{-1}\right)$ & & Co & $\mathrm{Ni}$ \\
\hline HZSM-5 & 100 & 625 & 19.62 & - & - \\
Co/HZSM-5 & 89.48 & 599 & 17.78 & 0.58 & - \\
Ni/HZSM-5 & 82.45 & 589 & 20.91 & - & 0.5 \\
\hline
\end{tabular}


Table 4 Pyrolytic products from Py-GC/MS of Jatropha waste without and with catalysts pyrolyzed at $500^{\circ} \mathrm{C}$

\begin{tabular}{|c|c|c|c|c|c|c|c|c|c|c|c|}
\hline \multirow[t]{2}{*}{ Catalysts } & \multirow{2}{*}{$\begin{array}{c}\text { Jatropha: } \\
\text { Catalyst }\end{array}$} & \multicolumn{2}{|c|}{ HC compounds } & \multicolumn{8}{|c|}{ Oxygenated compounds } \\
\hline & & $\begin{array}{c}\text { Aliphatic } \\
\text { HC }\end{array}$ & $\begin{array}{c}\text { Aromatic } \\
\text { HC }\end{array}$ & Phenol & Ketone & Ether & Ester & Alcohol & Acid & N-comp. & Sugar \\
\hline None & $1: 0$ & 1.0 & 3.03 & 5.09 & 7.52 & 3.72 & 1.99 & 3.0 & 50.7 & 20.31 & 3.66 \\
\hline HZSM-5 & $1: 1$ & 7.81 & 22.62 & 3.16 & 3.48 & 0 & 2.03 & 0 & 20.5 & 35.35 & 5.04 \\
\hline Co/HZSM-5 & & 7.37 & 24.59 & 5.38 & 1.79 & 0 & 4.79 & 1.92 & 11.6 & 41.69 & 0.89 \\
\hline Ni/HZSM-5 & & 13.86 & 20.9 & 3.10 & 2.71 & 0 & 1.9 & 0 & 11.01 & 44.88 & 1.64 \\
\hline HZSM-5 & $1: 5$ & 0.77 & 87.85 & 0.6 & 0 & 0 & 1.36 & 0 & 0 & 9.42 & 0 \\
\hline Co/HZSM-5 & & 2.81 & 85.19 & 0 & 0.2 & 0 & 1.35 & 0 & 0 & 10.42 & 0 \\
\hline Ni/HZSM-5 & & 3.32 & 85.97 & 0.31 & 0 & 0 & 1.53 & 0 & 0 & 8.83 & 0 \\
\hline HZSM-5 & $1: 10$ & 0 & 96.3 & 0 & 0 & 0 & 1.16 & 0.55 & 0.36 & 1.61 & 0 \\
\hline Co/HZSM-5 & & 0.80 & 94.53 & 0 & 0 & 0 & 0.97 & 0 & 0 & 3.7 & 0 \\
\hline Ni/HZSM-5 & & 1.74 & 95.81 & 0 & 0 & 0 & 0.67 & 0 & 0 & 1.78 & 0 \\
\hline
\end{tabular}




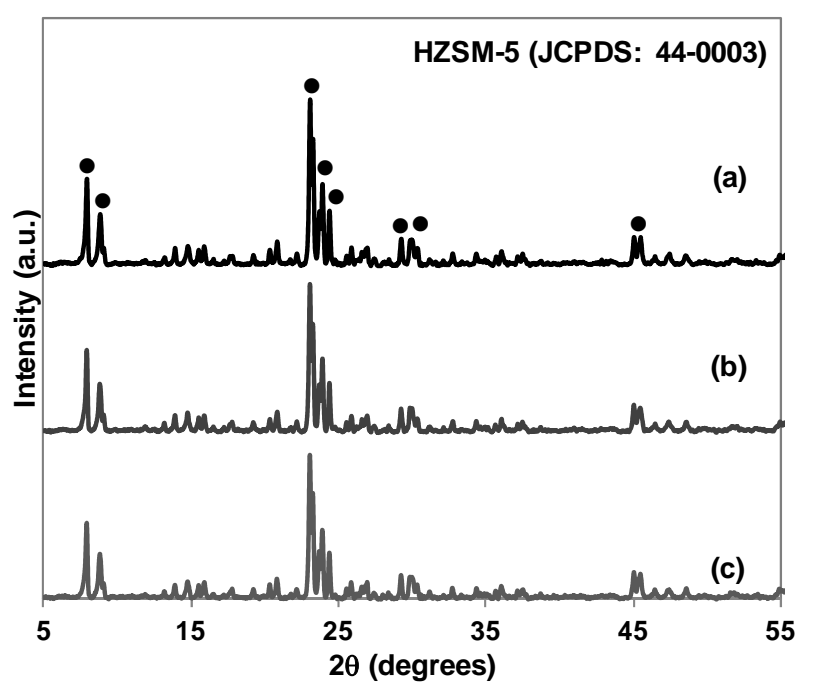

Fig. 1 XRD patterns of (a) HZSM-5, (b) Co/HZSM-5, and (c) Ni/HZSM-5 

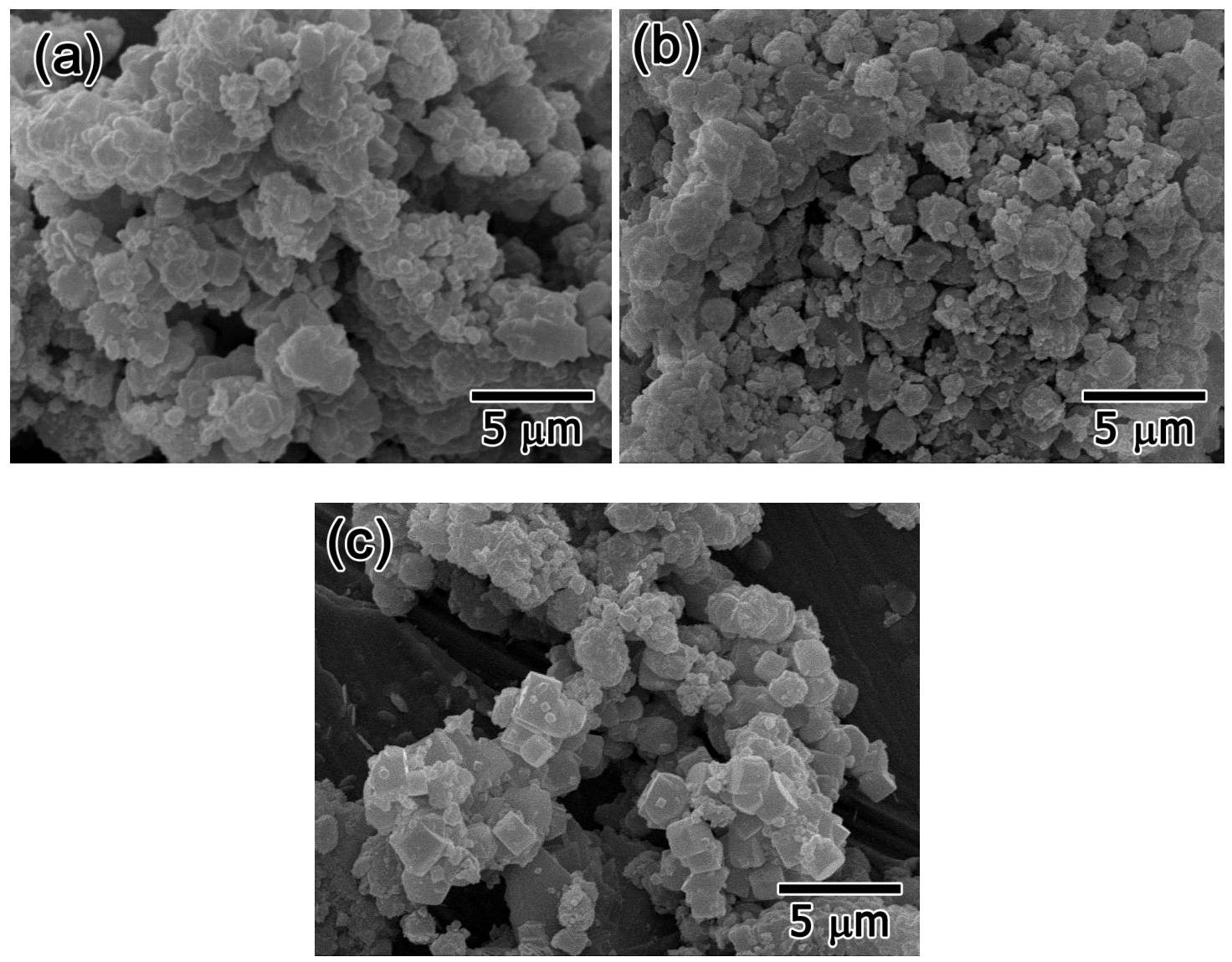

Fig. 2 SEM micrographs of (a) HZSM-5, (b) Co/HZSM-5, and (c) Ni/HZSM-5 

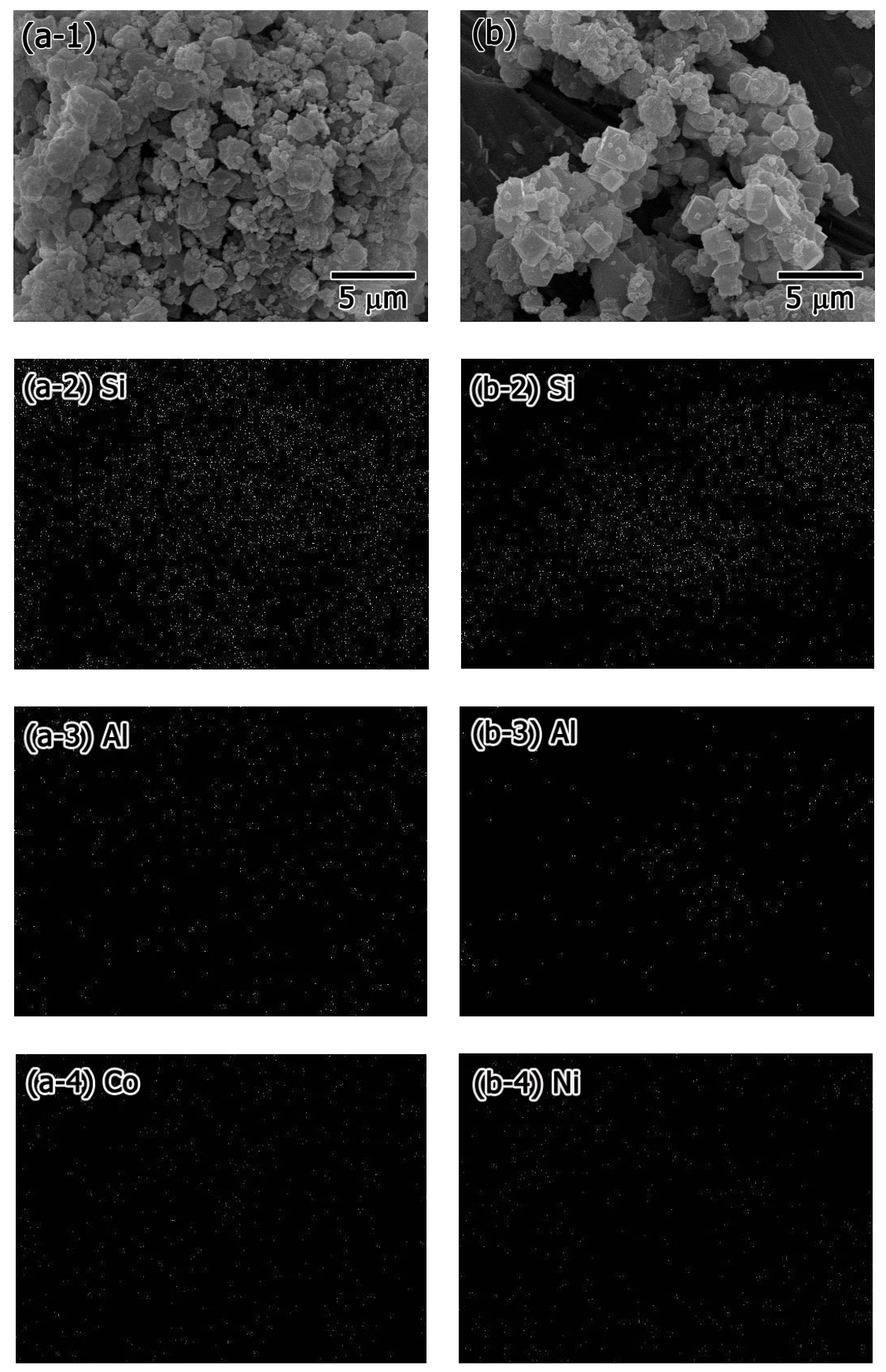

Fig. 3 X-ray mapping of elemental constituents within the microstructure of (a) Co/HZSM-5, and (b) Ni/HZSM-5 


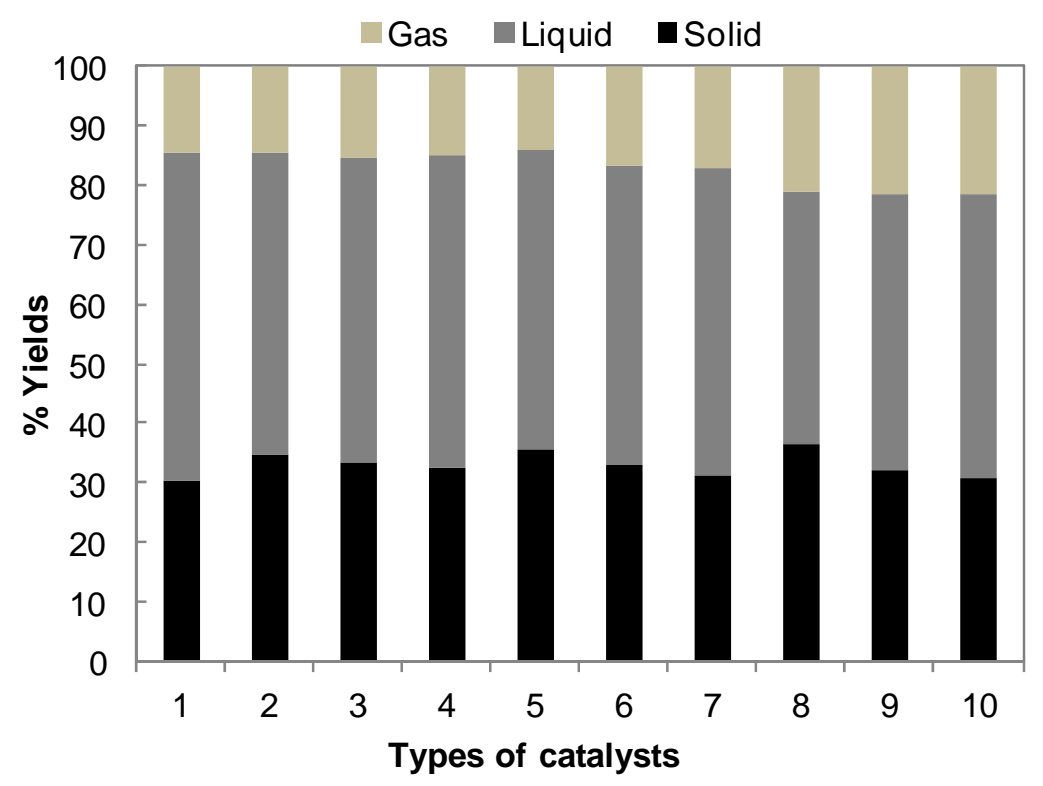

Fig. 4. Product yields after pyrolysis of Jatropha waste using Py-GC/MS with different catalysts; (1) No catalyst, (2) HZSM-5, (3) Co/HZSM-5, (4) Ni/HZSM-5 ((2)-(4) referred the Jatropha to catalyst ratios =1:1); (5) HZSM-5, (6) Co/HZSM-5, (7) Ni/HZSM-5, ((5)-(7) referred the Jatropha to catalyst ratios =1:5); (8) HZSM-5, (9) Co/HZSM-5, (10) Ni/HZSM-5 ((8)-(10) referred the Jatropha to catalyst ratios $=1: 10$ ). 


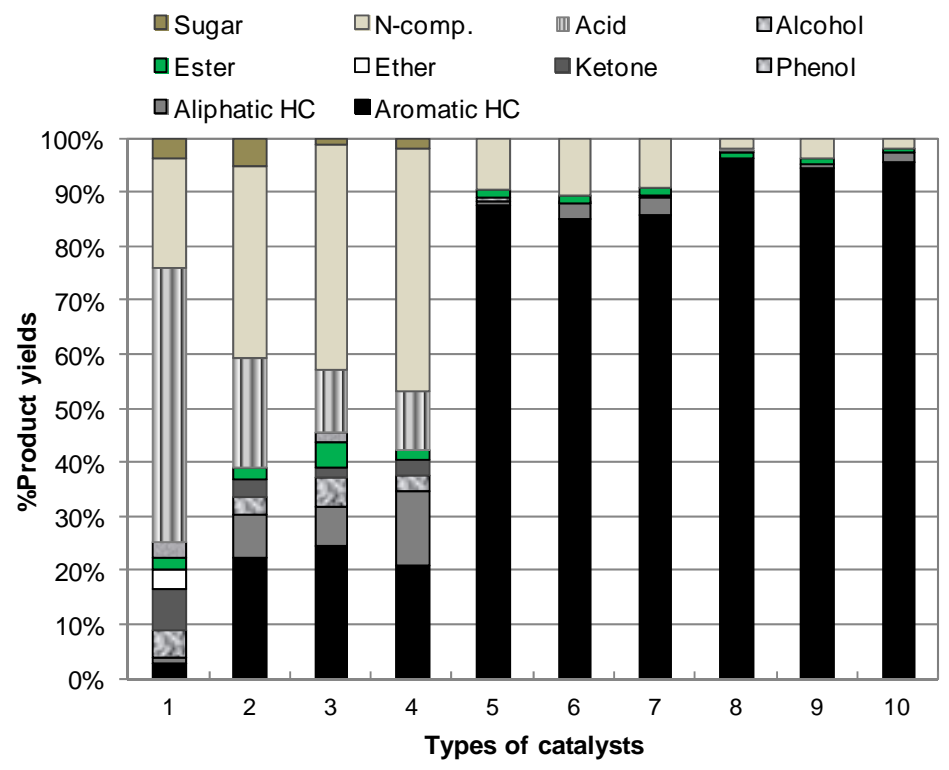

Fig. 5. Pyrolytic liquid yields detected from Py-GC/MS of Jatropha waste with different catalysts: (1) No catalyst, (2) HZSM-5, (3) Co/HZSM-5, (4) Ni/HZSM-5 ((2)-(4) referred the Jatropha to catalyst ratios =1:1); (5) HZSM-5, (6) Co/HZSM-5, (7) Ni/HZSM-5, ((5)-(7) referred the Jatropha to catalyst ratios =1:5); (8) HZSM-5, (9) Co/HZSM-5, (10) Ni/HZSM-5 ((8)-(10) referred the Jatropha to catalyst ratios $=1: 10)$. 

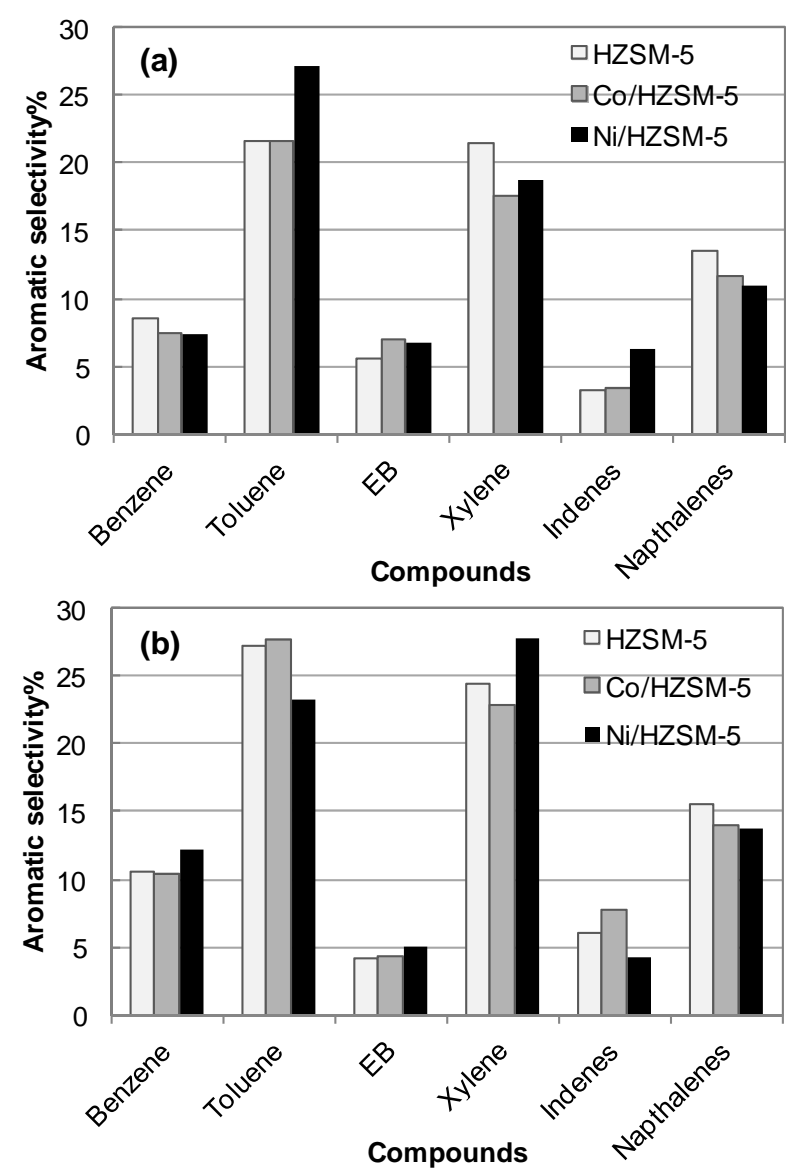

Fig. 6 Aromatic selectivity of pyrolytic products from Py-GC/MS of Jatropha waste with different catalysts, pyrolyzed at $500^{\circ} \mathrm{C}$ : (a) Jatropha:Catalyst $=1: 5$ and (b) Jatropha:Catalyst $=1: 10$ 